\title{
Synthesis and Thermal Decomposition Mechanism Study of a Novel Iridium Precursor
}

\author{
Xin Yan ${ }^{1, a}$, Tao $\mathrm{Ai}^{1}$, Xinhua Su ${ }^{1}$, Zhenjun Wang ${ }^{1,2}$, Guodong Sun ${ }^{1}$ and Peng Zhao ${ }^{1}$ \\ ${ }^{1}$ School of Materials Science and Engineering, Chang'an University, Xi'an, 710061, P.R. China \\ ${ }^{2}$ Engineering Research Central of Pavement Materials, Ministry of Education of P.R. China, Chang'an University, Xi'an 710061, P.R. China
}

\begin{abstract}
Ir}(\mathrm{TFA})_{3}$ (TFA=1,1,1-trifluoro-2,4-pentanedionate) metal complexes with high purity was successfully synthesized. The metal complexes have been characterized by elemental analysis, infrared spectroscopy, nuclear magnetic resonance spectroscopy. The volatility of metal complexes was studied by thermogravimetry analysis. And a possible decomposition mechanism was studied by mass spectroscopic analysis method. The novel iridium complexes can be severed as precursor in metalorganic chemical vapor deposition of iridium films. iridium films were deposited by metalorganic chemical vapor deposition method, and the $\operatorname{Ir}(\mathrm{TFA})_{3}$ complex was used as precursor. The iridium thin films were characterized by X-ray diffraction and scanning electron microscopy in order to determine crystallinity and surface morphology.
\end{abstract}

\section{Introduction}

Noble metal thin films have been extensively studied by both the traditional and microelectronics industries for potential applications such as anti-corrosion and antioxidation coating [1-2], or in the manufacture of bottom electrodes for high-density memory devices and ferroelectric capacitors [3-5]. Iridium is considered to be one of the best of these transition metal elements, as it possesses a high work function, a stable conductive oxide phase, $\mathrm{IrO}_{2}$, and excellent electrical properties [6]. Although physical sputtering [7] seems to be a good choice of method for depositing such iridium metalcontaining thin films, metalorganic chemical vapor deposition (MOCVD) will eventually become the preferred method because of its several major advantages, i.e., good conformal coverage, selective deposition on the substrate surface, the capacity for scale-up production with high throughput, and the ability to produce metalstable materials at low temperature [8].

Various iridium precursors have been studied [9-18] in recent years. Hoke [9] and Sun [10] has used cyclooctadiene complexes of iridium co-dosed with $\mathrm{O}_{2}$ for MOCVD iridium films growth and obtained pure iridium films at temperature between $122^{\circ} \mathrm{C}$ and $35^{\circ} \mathrm{C}$. Goto [11],Vargas [12],Gelfond[13] and Sun[14] have used tris-acetylacetonate iridium as precursor and obtained pure iridium films at temperature between 180 ${ }^{\circ} \mathrm{C}$ and $350{ }^{\circ} \mathrm{C}$. Tris-(allyl)-iridium, an air sensitive precursor, was used to produce clean deposits at temperature $100{ }^{\circ} \mathrm{C}$, under $\mathrm{H}_{2}$, on $\mathrm{SiO}_{2}$ substrates[15].Among these precursors, Trisacetylacetonate iridium $\left(\operatorname{Ir}(\mathrm{AA})_{3}\right)$ complex was the best choice due to its excellent air stability. However its high melting point and low volatility limited its possible use field. It was suggested [16] that the volatility of metal $\beta$ diketonates complex would be improved if the fluorine substitution were introduced onto the $\beta$-diketonates ligand. In this paper, iridium fluorinated $\beta$-diektonates complex was successfully synthesized from $\mathrm{IrCl}_{3}$ and HTFA in $\mathrm{CCl}_{4}$. The structure of $\operatorname{Ir}(\mathrm{TFA})_{3}$ was characterized by elemental analysis, infrared spectroscopy (IR), nuclear magnetic resonance (1H-NMR) spectroscopy. The volatility of metal complex was studied by thermogravimetry (TG) analysis. And a possible decomposition mechanism was studied by mass spectroscopic analysis method.

Iridium thin films were prepared by MOCVD on glass substrates, and iridium fluorinated $\beta$-diektonates complex was used as precursor. The structure and morphology of the iridium thin films were characterized by X-ray diffraction (XRD) and scanning electron microscopy(SEM).

\section{Experimental}

\subsection{Preparation of $\operatorname{Ir}(\text { TFA })_{3}$ complex}

$\operatorname{Ir}(\mathrm{TFA})_{3}$ was obtained by the following procedure. Firstly, the $\mathrm{IrCl}_{3}$ solution was prepared by the reduction of $\mathrm{H}_{2} \mathrm{IrCl}_{6} \cdot \mathrm{nH}_{2} \mathrm{O}$. Secondly, The ligand trifluoroacetylacetone was synthesized by claisen condensation method. Thirdly, the ligand dissolved in a $2 \mathrm{M} \mathrm{NH}_{3} \cdot \mathrm{H}_{2} \mathrm{O}$ aqueous solution was dropped continuously to the $\mathrm{IrCl}_{3}$ in ethanol solution, followed by the addition

\footnotetext{
a Corresponding author: yan_xin007@163.com
} 
of $2 \mathrm{M} \mathrm{NH}_{3} \cdot \mathrm{H}_{2} \mathrm{O}$ aqueous solution to adjust the $\mathrm{pH}$ value of the mixture to 8.5. At last, the reaction mixtures have been refluxed for $8 \mathrm{~h}$. The resulting product was collected by filtration and dried under vacuum. The product was purified by recrystallization (system a benzene-hexane).

\subsection{Characterization of $\operatorname{Ir}(\text { TFA })_{3}$ complex}

The purity of the sample was characterized by carbon and hydrogen elemental analysis in a Perkin-Elmer 2400 $\mathrm{CHN}$ instrument. Nuclear magnetic resonance (1H-NMR) spectrum was obtained using an INOVA 400 spectrometer for sample dissolved in $\mathrm{CDCl}_{3}$. The Fourier transform infrared (FTIR) spectrum was recorded from 400 to $4000 \mathrm{~cm}^{-1}$ using the FTIR spectrometer, model WQF-310. The sample was mixed with $\mathrm{KBr}$ powder, pressed into a self-supporting disk, and then placed at the center of the IR cell for experiment. The thermogravimetry (TG) analysis was measured in a $\mathrm{N}_{2}$ flow of $60 \mathrm{ml} / \mathrm{min}$ at a heating rate of $10{ }^{\circ} \mathrm{C} / \mathrm{min}$ in ambient pressure from $25^{\circ} \mathrm{C}$ to $400{ }^{\circ} \mathrm{C}$ using TG/Q50. In order to obtain more explicit and idiographic about decomposition mechanism of the metal complex, a mass spectrometer (model HP 5989B) was used to obtain the cracking patterns of $\operatorname{Ir}(\mathrm{TFA})_{3}$. The sample was ionized by the electron impact (EI) method and the scanned mass range was from 1 to $800 \mathrm{~m} / \mathrm{z}$.

\subsection{Iridium thin films prepared by MOCVD}

The MOCVD experiments were performed in a vertical hot-wall reactor. The deposition temperature used was at $350-500{ }^{\circ} \mathrm{C}$. The iridium films were deposited on glass substrates. The phase composition and structure of the iridium thin films were characterized by X-ray diffraction (XRD) (RigakuD/Max-2400) with $\mathrm{CuK} \alpha$ radiation. The surface morphologies of the thin films were examined using a scanning electron microscope (Hitachi-S4800).

\section{Results and discussion}

\subsection{Characterization of $\operatorname{Ir}(\text { TFA })_{3}$ complex}

The IR spectroscopy of $\operatorname{Ir}(\text { TFA })_{3}$ and HTFA were showed in (Fig. 1). The peak $1612 \mathrm{~cm}^{-1}, 1525 \mathrm{~cm}^{-1}$ represent the vibration modes and stretching modes of the $\mathrm{C}-\mathrm{O}$ and $\mathrm{C}$ $\mathrm{C}$ bonds in the complex ring structure. Compare to the free ligand, the vibration modes and stretching modes of the C-O and C-C bonds present to $1715 \mathrm{~cm}^{-1}, 1640 \mathrm{~cm}^{-1}$. The peaks brought visible red shift respectively. The results showed that the ligand have chelated with iridium. The other peaks can be divided into four parts :(1)The peaks between 1300 and $1400 \mathrm{~cm}^{-1}$ and those between 900 and $1100 \mathrm{~cm}^{-1}$ are due to the $\mathrm{CH}_{3}$ and $\mathrm{CF}_{3}$ groups; (2) peaks between 1100 and $1300 \mathrm{~cm}^{-1}$ and those between 700 and $900 \mathrm{~cm}^{-1}$ can be assigned to various vibrational modes of the $\mathrm{C}-\mathrm{CF}_{3}$ bond;(3) peaks around $800 \mathrm{~cm}^{-}$ ${ }^{1}$ represent the out-of-plane bending modes of the $\mathrm{C}-\mathrm{H}$ bond between the two carbonyl groups; and (4) peaks at
451 and $669 \mathrm{~cm}^{-1}$ are due to the stretching mode of the Ir-O bond.

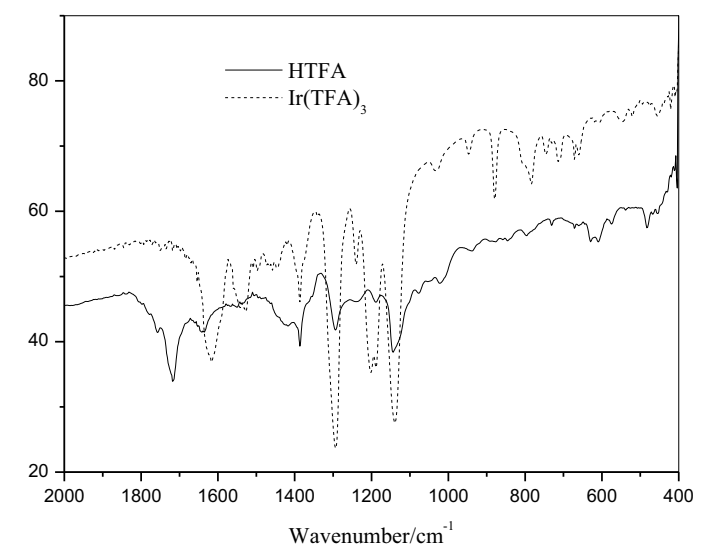

Figure 1. IR spectroscopy of $\operatorname{Ir}(\mathrm{TFA})_{3}$ and HTFA

The purity of the complex was checked by carbon and hydrogen elemental analysis. Anal. Calcd. for $\mathrm{IrC}_{15} \mathrm{H}_{12} \mathrm{O}_{6} \mathrm{~F}_{9}\left(\operatorname{Ir}(\mathrm{TFA})_{3}\right)$ : C 27.66, $\mathrm{H}$ 1.857. Found: $\mathrm{C}$ $27.65, \mathrm{H} 1.853$. The results showed the $\operatorname{Ir}(\mathrm{TFA})_{3}$ was synthesized successfully with high purity. The NMR spectroscopy has been applied for a more detailed investigation of the organometallic structure of the complex to complement the elemental analyses and IR data forwards. In the ${ }^{1} \mathrm{H}-\mathrm{NMR}$ spectrum of $\operatorname{Ir}(\mathrm{TFA}) 3$,there are two peaks at 2.123 and $5.897 \mathrm{ppm}$, which can be assigned, respectively, to the methyl groups protons $\left(\mathrm{R}_{1}: \mathrm{CH}_{3}\right)$ and the proton boned to the carbon between the two carbonyl groups $\left(\mathrm{R}_{2}: \mathrm{CH}\right)$ in TFA. The relative area ratio of the two peaks is close to the ratio of proton quantities in the two groups correspondingly, which is $\mathrm{R} 1 / \mathrm{R} 2=3$. The results concluded from $1 \mathrm{H}-\mathrm{NMR}$ spectrum confirm that the prepared $\operatorname{Ir}(\mathrm{TFA})_{3}$ is of high purity, in agreement with elemental analysis.

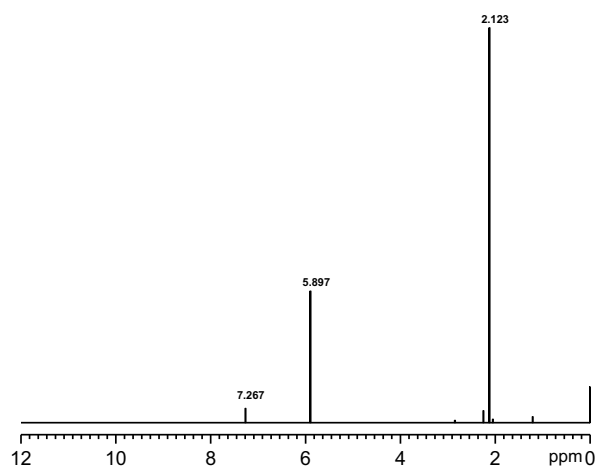

Figure 2. ${ }^{1} \mathrm{H}-\mathrm{NMR}$ spectrum of $\operatorname{Ir}(\mathrm{TFA})_{3}$

\subsection{TG analysis}


Fig. 3 is the TG curves of the samples in N2 which shows the sublimation features of $\operatorname{Ir}(\mathrm{TFA})_{3}$ and $\operatorname{Ir}(\mathrm{AA})_{3}$. The $\operatorname{Ir}(\mathrm{TFA})_{3}$ maintains its initial weight up to about $180{ }^{\circ} \mathrm{C}$ in $\mathrm{N}_{2}$ corresponding its sublimation temperature, then starts to lose weight significantly above $230{ }^{\circ} \mathrm{C}$, and no further weight loss appears up to $290{ }^{\circ} \mathrm{C}$. The residue amount is about $2.53 \%$ of the initial weight. $\operatorname{The} \operatorname{Ir}(\mathrm{AA})_{3}$ maintains its initial weight up to about $220 \mathrm{oC}$ in $\mathrm{N} 2$ corresponding its sublimation temperature, then starts to lose weight significantly above $260{ }^{\circ} \mathrm{C}$, and no further weight loss appears up to $300{ }^{\circ} \mathrm{C}$. The residue amount is about $2.76 \%$ of the initial weight. The $\mathrm{TG}$ results show that the $\operatorname{Ir}(\mathrm{TFA})_{3}$ is high volatile than $\operatorname{Ir}(\mathrm{AA})_{3}$, which may be served as precursor in MOCVD of iridium films.

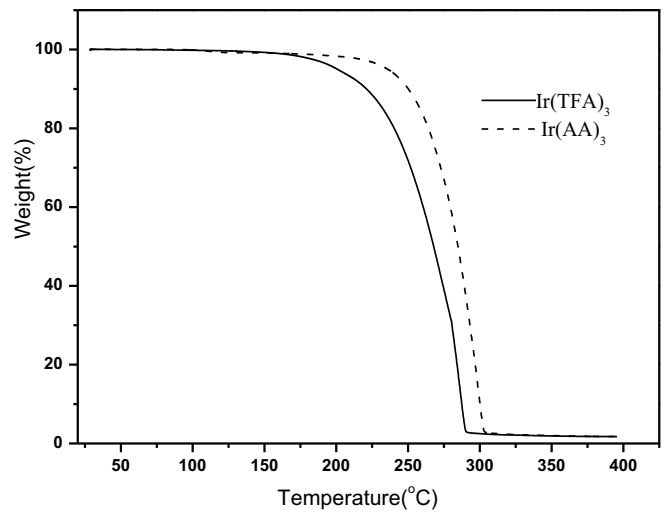

Figure 3. Thermogravimetry curves of $\operatorname{Ir}(\mathrm{TFA})_{3}$ and $\operatorname{Ir}(\mathrm{AA})_{3}$.

\subsection{Mass spectroscopic analysis}

Mass spectrometry was carried out to provide more insight into the mechanism of decomposition and helpful information to MOCVD deposition [17]. Fig. 4 shows a typical mass spectrum for $\operatorname{Ir}(\mathrm{TFA})_{3}$ at $160 \mathrm{oC}$, major peaks of highest mass are observed at $\mathrm{m} / \mathrm{z}=652,650,499,497,85,69,43 \quad$ corresponding to [193 $\operatorname{Ir}($ TFA $) 3]+, \quad[191 \operatorname{Ir}($ TFA $) 3]+, \quad$ [193 $\operatorname{Ir}($ TFA $) 2]+$, [191Ir(TFA)2]+,+OCCH3COCH2,+CF3,+OCCH3, respectively.

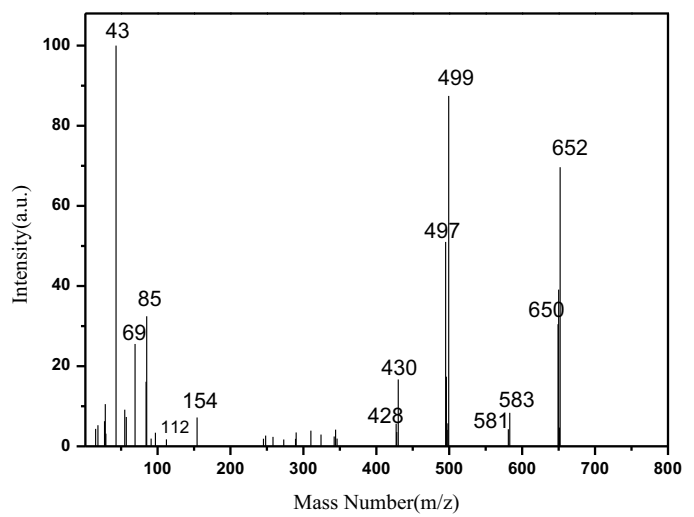

Figure 4. Mass spectrum of $\operatorname{Ir}(\mathrm{TFA})_{3}$ taken at $160^{\circ} \mathrm{C}$.
The mass fragments reveal a possible decomposition process, which was described in Fig.5: (a) at the beginning the $\mathrm{CF} 3$ group detached from TFA ligand, and then the $\mathrm{OCCHCOCH}_{3}$ group in the same TFA group; (b) the obtained [193Ir(TFA)2]+ will continue to decompose similar to (a). The CF3 group will be lost from TFA ligand, and then the OCCHCOCH3 group in the same TFA group;(c) the obtained [193Ir(TFA)]+ will lose the $\mathrm{Ir} 3+$, then the $[\mathrm{CH} 3 \mathrm{COCH} 2 \mathrm{COCF} 3]+$ will decompose according to two different processes. At last, the $+\mathrm{CF} 3$, $[\mathrm{COCH} 2 \mathrm{COCH} 3]+,[\mathrm{COCH} 3]+$ ion were obtained in the system.
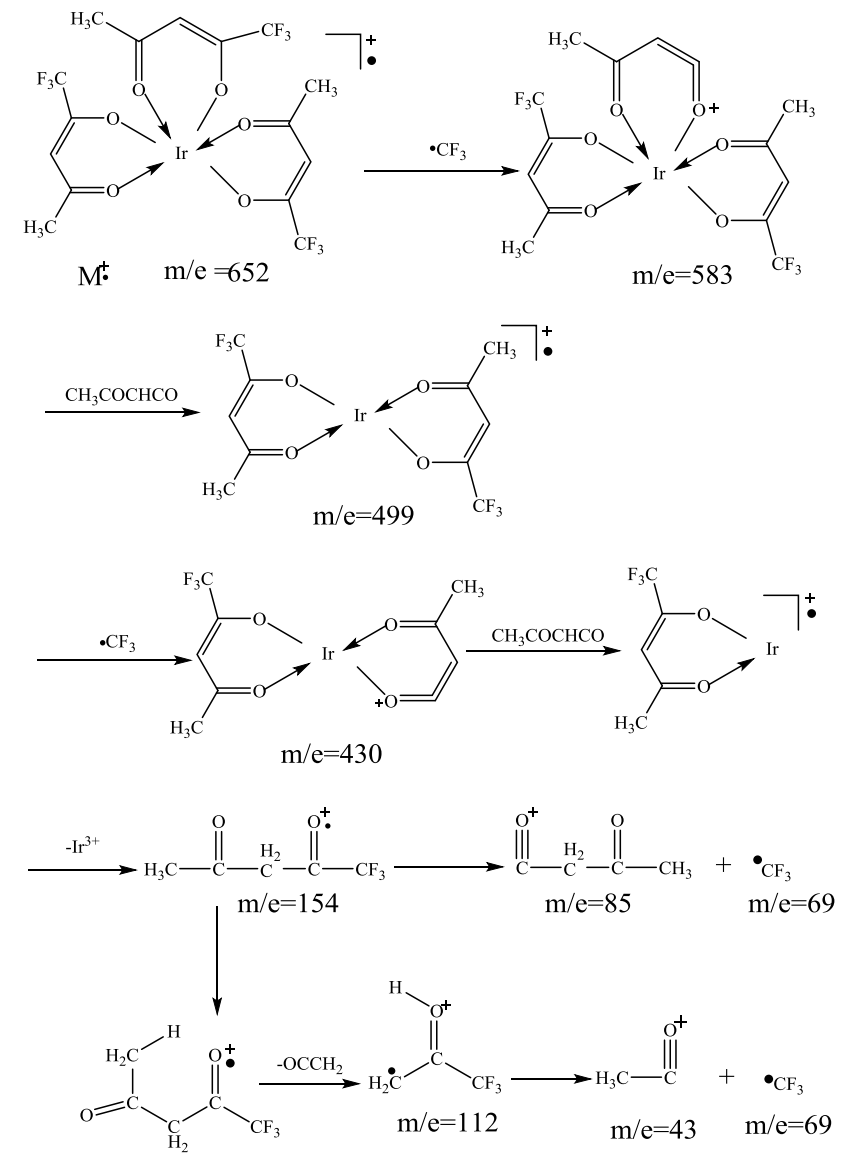

Figure 5. Possible decomposition mechanism of $\operatorname{Ir}(\mathrm{TFA})_{3}$.

\subsection{Characterization of Iridium thin films}

Iridium thin films were prepared by MOCVD on glass substrates. The structure and morphology of the iridium thin films were characterized by X-ray diffraction (XRD) and SEM. Fig. 6 displays the XRD patterns of the Ir films on glass substrates at the growth temperature of $400^{\circ} \mathrm{C}$. The $2 \theta$ scan data of the films exhibited strong $2 \theta$ peaks at $40.8^{\circ}, 47.4^{\circ}$ and $69.3^{\circ}, 83.6^{\circ}, 88.1^{\circ}$ respectively, corresponding to the (111), (200), (220), (311) and (222) peaks of Ir, revealing that the Ir films were fully polycrystalline and no evidence for a preferential orientation was found. 


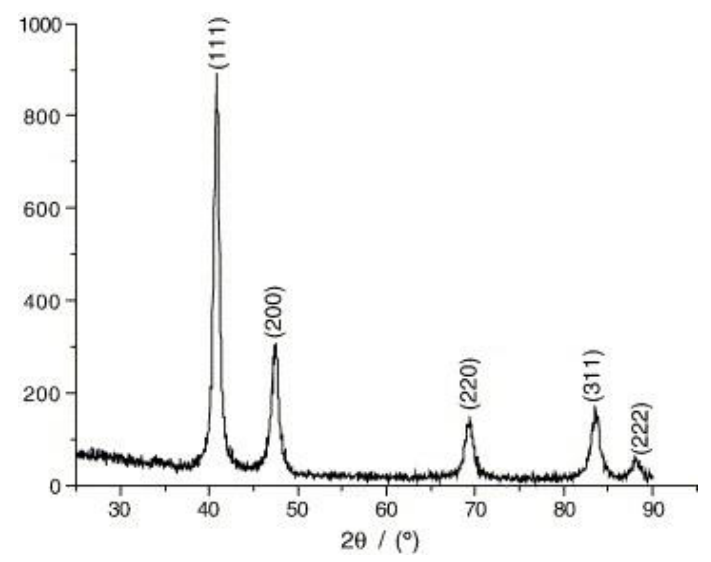

Figure 6. The XRD pattern of iridium film deposited on glass substrate.

Fig.7 shows the surface morphology images of iridium thin films. Thus resultant iridium films were dense, smooth and homogeneous, with an average grain size of 10-40 nm. We speculate that growth starts probably with the isolated iridium clusters, which grow three dimensionally. Thus the growth mechanism follows the Volmer-Weber model. More detailed investigations will be presented elsewhere.

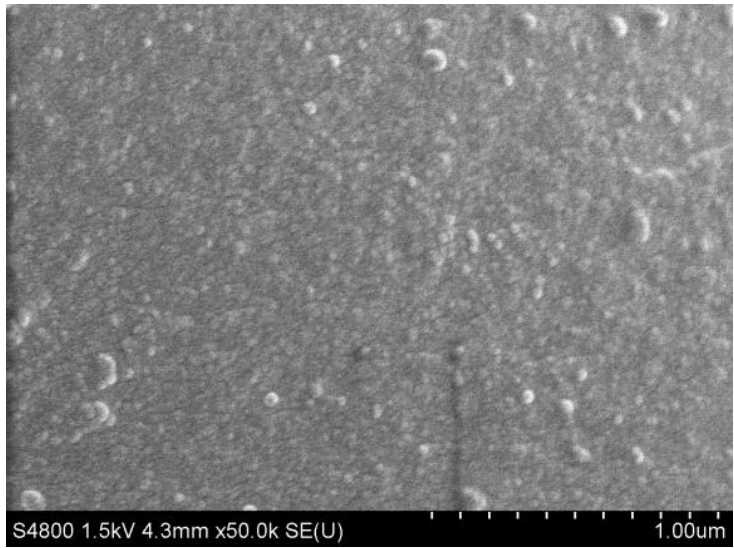

Figure 7. The SEM image of iridium thin film.

The energy dispersive spectrdmeter (EDS) data of the iridium films is shown in Fig.8. The spectra reveal the presence of the $\mathrm{Si}, \mathrm{Au}, \mathrm{Ca}, \mathrm{Cu}$, Ir elements in the films. Among these elements, $\mathrm{Si}, \mathrm{Ca}$, and $\mathrm{Cu}$ are from the glass substrates and the equipment itself, and Au was deposited by sputtering in order to improve the films conductivity. Thus, the presence of Ir in the films is further confirmed by the EDS data whereby the Ir peak is detected in the EDS spectra.

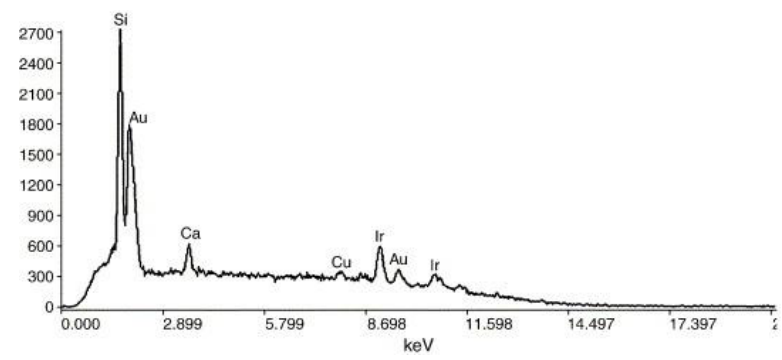

Figure 8. The EDS analysis of the iridium film deposits at $400^{\circ} \mathrm{C}$ on glass substrates.

\section{Conclusions}

$\operatorname{Ir}(\mathrm{TFA})_{3}$ complex powder with high purity was successfully synthesized from $\mathrm{IrCl}_{3}$ and HTFA in ethanol/aqueous solution followed by recrystallization from benzene-hexane system. The TG analysis shows that the complex sublimates from $180{ }^{\circ} \mathrm{C}$ to $29{ }^{\circ} \mathrm{C}$, and the residue amount is about $2.53 \%$ of the initial weight. The TG results show that the $\operatorname{Ir}(\mathrm{TFA})_{3}$ is high volatile than $\operatorname{Ir}(\mathrm{AA})_{3}$, which may be served as precursor in MOCVD of iridium films. The possible decomposition mechanism was obtained by mass spectroscopic analysis method. $\operatorname{Ir}(\mathrm{TFA})_{3}$ complex powder was used as precursor, then the iridium thin films were successfully synthesized on glass substrates at $400^{\circ} \mathrm{C}$ by the MOCVD method. Deposited films were found to consist of islands grown on the glass substrate. The growth mechanism follows the Volmer-Weber model.

\section{Acknowledgements}

This work was supported by the Natural Science Basis Research Plan in Shaanxi Province of China (No2015JM2070,No2015JQ5149) and the Fundamental Research Funds for the Central Universities (No.310831153504) and the National Natural Science Foundation of China (No.51402024)

\section{References}

1. J.Hamalainen, M Ritala, M.Leskela, Chem Mat, 26 786 (2014).

2. L.A Zhu, S.X Bai, H. Zhang, Int J Refract Met H, 44,42 (2014).

3. S.Sakka, H. Kozuka, J Sol-Gel Sci Technol, 13,701(1998).

4. B. J Bae, K. M Lee, J .E Lim, Integrated Ferroelectrics, 68, 123 (2004).

5. A Das , S Maikap, WC Li, Jap J App Phy, 48 , 78(2009).

6. X.J Liu, L. Zhu, X.F Li, J Vac Sci Technol, 32, 134 (2014).

7. L.S Zhang, Z.G Shao, , H.M Yu, J Electroanal Chem, 688262 (2013) .

8. K. Kuribayashi, Y. Fujita, H. Isige, Mater Sci Eng BSolid,109,188 (2004).

9. J. B Hoke, E.W Stern, H. H Murray, J Mater Chem, 1,551 (1991).

10. Y.M Sun, X. M Yan, N.Mettlach, J Vac Sci Technol, A18,346 (2000) .

11. T.Goto, J. R Vargas, T. Hirai, Mater Sci Eng, A217/218223 (1996) .

12. J. R Vargas, T. Goto, W. Zhang, Appl Phys Lett, 65 1094 (1994)

13. R.S Chen, Y. S Chen, Y. S Huang, Chem Vap Deposition, 9301 (2003).

14. Y. M Sun, J. P Endle, K. Smith, Thin Solid Films, 346,100 (1999). 
15. Y L Chen, C C Hsu, Y H Song, et al, Chem Vap Deposition, 12,442 (2006).

16. J A Samuels, E B Lobkovsky, W E Streib, et al, J Am Chem Soc, 115,5093 (1993).

17. M. L Hitchman, S .H Shamlian, G. G Condorelli, J Alloys Compounds, 251 ,297 (1997). 